\title{
The Effectiveness of the Group Learning Strategy in Developing the Creative Capabilities of the Skillful Performance in Art Education among Sixth Grade Students
}

\author{
Ammar Abdul Hamid Katran
}

Department of Preparation and Training/ Division of Educational Research and Studies, General Directorate of Education in Baghdad Al-Karkh 2, Ministry of Education, Iraq

Email: Alkhafajiammar.aa@gmail.com

\section{ABSTRACT}

The current research aims to:

Identify the effectiveness of using the combination learning strategy in developing creative capacities (flexibility, details) for the skillful performance of art education among sixth grade students. For the purpose of verifying the objective of the research, the researcher assumed the following null hypotheses:

- There are no statistically significant differences between the average scores of the experimental group taught using the combination learning strategy and the control group that is taught by the traditional method at the level of $(0.05)$ in the pretest.

- There are no statistically significant differences between the mean scores of the experimental group and the control group at the level of (0.05) in the post test.

- There are no statistically significant differences between the average scores of the experimental group that are taught using the combination learning strategy at a significance level (0.05) in the pre and post test

- The current research sample included a group of sixth-grade primary students at Dar Al-Emara School from the research community in the Baghdad Education Directorate Al-Karkh 2.

- The results of the research revealed the superiority of the experimental group over the control group when implementing the experiment.

Article Received: 18 October 2020, Revised: 3 November 2020, Accepted: 24 December 2020

\section{Introduction}

The progress of art education is not more than a skill in performing the artistic work or understanding the artistic work in an abstract way. Rather, building an idea that reflects the creative ability of the learner, which means encouraging the learner to discover new relationships and invent new ways to change reality, being a fertile field for innovation. And creativity, and that one of the basic goals of art education is to acquire creative capabilities in various aspects, because creativity in its concept is artificial and not natural, meaning that everyone has a capacity for creativity that is developed and taken into account by education. And the interest in developing creative abilities in teaching emerged using methods and methods of a number of researchers outside the content of the curriculum, and the use of these methods and strategies led to a change in the role of students in the educational process, as they became more positive and active, and also led to a change in the student-teacher relationship in the classroom.

\section{Definition of research}

\section{First: the research problem}

One of the main goals of teaching art education is the development of positive attitudes towards the subject and the student, who has a positive attitude towards art education, for sure, he will have a selfmotivation for the practice and artistic performance of his belief in the capabilities, information and skills he acquires that make the creativity process in 
a continuous and increasing growth. The development of creative capabilities through art education is one of the basic goals that the educational process seeks to achieve, as it develops research and development and creates an appropriate interactive environment between the contributions of the teacher and the student. It is not possible to develop the creative capabilities in the way the subject is taught if it is characterized by static, in other words. Not using modern methods by the teacher, which limits the contribution of the material to the development of creative abilities, and often the material is presented by the teacher as if it is limited to drawing and works and lack of familiarity with the material and its importance in developing creative abilities as a result of relying on the traditional method. Based on what was presented above, the researcher decided the necessity of using a modern teaching strategy that is compatible with the subject of art education and the possibility of its contribution to developing the creativity of sixth-grade students, which is the strategy of group learning, by building teaching plans that are taught according to this strategy.

\section{Second: The importance of research}

The researcher summarized the importance of the research with the following points:

1- The use of one of the modern educational trends, which is the use of an educational strategy, which is the collective learning strategy, which benefits those interested in teaching and research when planning to teach art education.

2- The interest of the research in developing creative capabilities in an unconventional way by using the group learning strategy, which depends on effort and regular thinking in a sequential manner.

3- It is possible to present experimental results that the authors of art education curricula may benefit from in choosing the appropriate teaching strategies in organizing and formulating art education content.

4- Empowering weak students in drawing and planning and developing their skills performance through the use of some creative abilities such as (flexibility, details)

\section{Third: The objective of the research}

Identify the effectiveness of using the combination learning strategy in developing the creative capabilities (flexibility, details) of the skillful performance in art education among sixth grade students.

\section{Fourth: Research hypotheses}

For the purpose of verifying the objective of the research, the researcher assumed the following null hypotheses:

- There are no statistically significant differences between the average scores of the experimental group taught using the combination learning strategy and the control group that is taught by the traditional method at the level of (0.05) in the pre-test.

- There are no statistically significant differences between the average scores of the experimental group and the control group at the level of (0.05) in the post test.

- There are no statistically significant differences between the average scores of the experimental group that are studied using the combination learning strategy at a significance level (0.05) in the pre and post test.

\section{Fifth: Research limits}

1- Time limit: the academic year 2019-2020.

2- The spatial boundary: The General Directorate of Education in Baghdad AlKarkh / 2. 
3- The objective limit: the development of creative capabilities in planning and drawing (flexibility, details).

4- The human limit: Sixth grade students at Dar Al Emara School

\section{Sixth: Terminology}

\section{Collective learning:}

(Joyce 1980) defined it as: "The flexible state of the performances and methods, the teacher can develop them continuously in the pursuit of reaching the academic goals that he has set" (joyce, 1980: p12) and defined it (Al-Shibli 1997) as: "a comprehensive plan that the teacher undertakes, starting from formulating goals and setting implementation procedures down to methods Calendar of its teaching activities "(Al-Shibli, 1997: 19). As for the definition of the procedural researcher, he defined it as: "A set of behavioral plans and goals set by the art education teacher, and how to implement them in order to reach effective evaluation methods and develop the skillful performance in planning and drawing.

\section{2- Creative Capabilities:}

(Al-Rashid 2000) defined it as: A group of businesses needs skill, precision and identification of an innovative person who has capabilities such as fluency, flexibility, originality and details, because only those who have these capabilities can do these works. (Al-Rasheed, 28: 2000). (Mansour and AlTuwaijri 2000) defined it as: A creative person is one who is distinguished by the ability to focus on solving a specific problem for a long time.

(Mansour and Al-Twaijri, 2000: 27). The researcher defined it procedurally as: a mental process based on creating new relationships between previous experiences and organizing them into shapes and images, enabling it to produce a number of diverse achievable responses, and that this response is characterized by flexibility, details and use in drawing and planning.
A theoretical framework and previous studies

Theoretical framework:

\section{The first axis: the group learning strategy}

A strategy for teaching a specific skill by following specific educational steps that took their roots from programmed education with cognitive steps that give the learner the opportunity to search, uncover, identify errors, and take methods that the teacher can continuously develop to reach the academic goals he has set.

Teaching steps using an additive learning strategy:

1- Selecting the educational content (lesson material).

2- An introductory introduction to the subject of the lesson.

3- Teaching the student what he will learn, its causes and consequences.

4- Determining the type of students who will study this complex.

5- Providing students with instructions and instructions about the educational complex.

6- Identify educational tools and supplies.

7- Determine the pre-test items in light of the behavioral goals.

8- Setting guide for answers and keys for correction.

9- Determining the skills required of the student.

10- A model for expected errors.

11- Determining the post-test items.

12-Defining references for the educational complex.

13-Conducting an evaluation of all parts of the educational process. (Drunk, 1989: 44)

\section{The second axis: creative capabilities}

The global theory is the most specific theory for the concept of creativity, as it talks about specific basic capabilities of creativity, and it can be determined that a person has a certain level of innovation and these abilities that (Guilford) identified are: fluency, flexibility, originality, and details. In order to 
understand the creative process, it is necessary to know its stages, which help the emergence of a creative product. (Al-Azza, 233: 2000).

\section{Stages of creative abilities:}

\section{First: Preparation}

No creative work can be done without a preparation process, it does not come from a void or coincidence, at this stage the individual is raised to find a solution to a specific problem, and he collects facts, data and information related to the subject to be produced as a creative work, analyzes, classifies and organizes them, determines the necessary skills and perceives the surrounding relationships (AlHarbi, 43: 2000)

\section{Second: Incubation}

After many attempts to reach a solution, this stage comes after thinking about all possible possibilities, where the individual appears as he has left the problem completely and resorts to several methods to divert his attention to the problem, where he is dominated by relaxation and apparent calm, so he goes for a walk or preoccupation with another topic. But it is a latency stage that may last for years or shorten for a few minutes.

\section{Third: Illumination}

It is the moment when the idea suddenly flashes to solve the problem that has always occupied a large area of mental activity during the preparation and incubation stages, and it is the decisive stage in the creativity process, so radiance is the experience that ends with solving the confusing mystery and satisfaction and satisfaction after a period of suffering.

\section{Fourth: Verification}

The process of creative penetration does not usually end with the inflection of ideas and the occurrence of brightness in the sense of what the life of the creators indicates, as there is a stage of testing the new idea and knowing the extent of its validity and referral, meaning that there is a need and necessity to make more effort and follow-up to overcome the obstacles that obstruct the creative penetration, and this stage is considered as an evaluation The ideas that have been reached and the possibility of their application. (Jerwan, 2002: 139).

\section{Types of creative abilities:}

\section{Fluency}

Speed and ease in issuing judgments and solutions to problems commensurate with the requirements of the real environment, where the ideas do not originate from lack of knowledge, ignorance, or randomness, and are not based on a false and unacceptable assumption such as myths. The quantitative aspect of creativity.

\section{Flexibility}

It is the ability to differ or diversify ideas and solutions that the individual brings, and the ease with which the individual can change his position or his mental point of view as required by the problem or idea to be solved. (Al Street, 2000: 63)

\section{Originality}

The ability to rapidly produce ideas that meet certain conditions in a particular situation, such as if they are rare ideas or ideas with indirect links, far from the exciting situation, or are skilled. Authenticity means expression in a way that is different from what most ordinary individuals express, in the sense of avoiding the usual methods and that the individual does not become like other people.

\section{Elaboration}

The ability to give more details or provide new additions to a specific idea, as the fine details are discovered and recognized and highlighted, it is to find the details to complete a complex and meaningful plan from simple lines. (Hegazy, 2001: 20).

\section{previous studies}

The first axis: Studies dealing with group learning The second axis: Studies dealing with creative abilities 
The first axis: Studies dealing with group learning. A study (Muhammad 2012):

The effect of using the group learning strategy on the skill performance of students of the Art Education Department in the planning course. The study aimed to demonstrate the impact of the group learning strategy on the skill performance of art education department students in the subject of practical planning according to the group learning strategy to develop students 'skills performance, and to measure the impact of the strategy on the skills performance of students of the Art Education Department at the College of Fine Arts, the first phase of the academic year 2010-2011. In order to verify the objectives of the research, the null hypothesis was determined between the average scores of the pre and post test, and the research community consisted of 113 students. A sample of (15) students was selected, and to meet the research requirements, (4) teaching plans were designed and a pre- and post-test skill performance was used. From the statistical means (Wilcoxen test), and after the research hypothesis is verified, conclusions and recommendations related to the research were drawn up after the results were presented and discussed.

The second axis: Studies dealing with the development of creative capabilities

Study (Basel Al-Qudah 2001). The study aimed to research "the effect of using the cooperative learning method on developing creative thinking for students of the eighth grade of middle school through science teaching. The study sample consisted of (139) male and female students, of whom (75) male and 82 female students were selected. The sample was by the random cluster method and they were distributed among four divisions in two schools, in each school a division representing the experimental group and another representing the control group, and to achieve the goal of the study, the researcher used the Torrance test for creative thinking, and the results indicated that there were no statistically significant differences attributed to sex or the interaction between the method and gender. The results also showed that there are statistically significant differences in the post-performance on the creative thinking test between the two groups of the experimental study and the control group and in favor of the experimental group that was studied using cooperative learning.

\section{Research methodology and procedures}

\section{First: Research Methodology}

To achieve the objectives or goal of the research, the researcher followed the experimental approach to research as it is the appropriate approach to the research procedures. It aims to study the effect of an independent variable on a dependent variable. Experimental research goes beyond the limits of quantitative description of the phenomenon, as it rises to treating certain variables under controlled conditions to verify how they occur. This research is not just a presentation of past incidents as in the historical method, or for diagnosing, observing and describing the present as in the descriptive approach, but rather is controlling the variables and controlling them in some of the situations indicating the phenomenon to be studied. (Abd al-Rahman and Zankana, 2007: 474).

\section{Experimental Design Second: Experimental Design:}

The choice of the appropriate experimental design for the research is of great importance, as it ensures the proper structure of the research and reaching reliable results in answering the research problem and achieving its hypotheses. Therefore, the researcher adopted in the current research the design of random groups (experimental and control) that are equivalent in some variables and by testing (before and after), as the research aims to identify (the effectiveness of the combination learning strategy in developing the creative abilities of the skillful performance in artistic education of sixth grade students), which required Preparing two 
groups, the first is an experimental and the second is a control group, as the experimental group is studied using the group learning strategy, while the control group is studied in the traditional way, according to what is shown in Table (1).

Table (1). Research Experimental Design

\begin{tabular}{|c|c|c|c|c|}
\hline $\begin{array}{l}\text { Measuring the } \\
\text { dependent } \\
\text { variable }\end{array}$ & $\begin{array}{l}\text { Dependent } \\
\text { variable }\end{array}$ & $\begin{array}{l}\text { Independent } \\
\text { variable }\end{array}$ & Statistical parity & the group \\
\hline \multirow{2}{*}{$\begin{array}{l}\text { Skill Performance } \\
\text { Evaluation Scale }\end{array}$} & \multirow{2}{*}{$\begin{array}{c}\text { Creative } \\
\text { capacity } \\
\text { development }\end{array}$} & $\begin{array}{l}\text { Group } \\
\text { learning } \\
\text { strategy }\end{array}$ & \multirow{2}{*}{$\begin{array}{c}\text { Previous experience } \\
\text { Chronological age }\end{array}$} & Experimental \\
\hline & & $\begin{array}{l}\text { traditional } \\
\text { way }\end{array}$ & & Control \\
\hline
\end{tabular}

\section{Third: research community}

Society is all the vocabulary of the phenomenon to be studied, that is, all things and individuals who make up the research community, as the current research community consists of students of the sixth grade of primary school in the General Directorate of Education in Baghdad Karkh II, for the academic year 2019-2020.

\section{Fourth: The research sample}

In some cases, researchers may resort to choosing one school that would be a place to conduct the experiment, and from this school people are chosen from the class on which the study is to be conducted, as it is not possible to adopt random selection of the members of the research sample from the community directly to distribute them to the experimental and control groups due to the nature of the educational system that is Random selection is not allowed at the individual level in the community, as the researcher chose one school to be a field for research application, which is the (Dar Al Emara) primary school, in which two divisions were chosen from the sixth grade, so the researcher randomly chose Division (A) to be the experimental group, and Division (B) For the control group, and the number of students in these two divisions reached (28 and 26) respectively, and then absentee and dropouts were excluded in order not to influence the results of the experiment, so the number of students for the two groups became (25 and 27) respectively, and to facilitate statistical procedures, the researcher excluded (2) from Students of the experimental group became (25) male and female students in each group, according to what is shown in Table No. (2).

Table (2) the research sample distributed according to groups

\begin{tabular}{|c|c|c|}
\hline $\begin{array}{c}\text { Number of } \\
\text { students }\end{array}$ & Division & the group \\
\hline 25 & $\mathrm{a}$ & Experimental \\
\hline 25 & $\mathrm{~B}$ & Control \\
\hline
\end{tabular}

\section{Fifth: Statistical equivalence}

To make sure that the extraneous variables are controlled, especially since the individuals 'choice of the two research groups was not random at the level of individuals from the research community, but rather at the people's level, as the researcher made equivalence in some variables that might affect the dependent variable without the independent. These variables are:

\section{A: Previous experience}

For the purpose of identifying what students in the control and experimental groups have of previous information about the scientific subject, the researcher prepared items for a cognitive achievement test to present the concepts contained 
in the material, the test consists of (10) items, and the researcher presented the test items to a group of specialists and experts in education Technical and methods of teaching it Appendix (1) And in light of their suggestions and observations, some paragraphs have been amended. The previous experience test was applied to the two research groups, where the researcher used the $\mathrm{T}$ test to find out the significance of the difference between the two groups, as it was found that there were no statistically significant differences at the level of $(0.05)$ as the calculated $T$ value $(0,996)$ was smaller than the table value of $(2,000)$. Accordingly, the two research groups are statistically equivalent in the variable of previous experience, noting that the test is binary as it reached the highest score (20) and the lowest score (10), and Table (3) shows that.

Table (3) parity in the variable of previous experience

\begin{tabular}{|c|c|c|c|c|c|c|c|}
\hline $\begin{array}{c}\text { Significance } \\
\text { level at } \\
(0.05)\end{array}$ & \multicolumn{2}{|c|}{ T-value } & variance & Standard deviation & SMA & $\begin{array}{c}\text { Sample } \\
\text { volume }\end{array}$ & Groups \\
\hline $\begin{array}{c}\text { Not } \\
\text { statistically } \\
\text { significant }\end{array}$ & 2,000 & 0,996 & 0,425 & 2,123 & 11,44 & 25 & Control \\
\cline { 2 - 8 }
\end{tabular}

\section{B: The chronological age}

After the researcher reviewed the ages of the members of the two groups from the school records, it was found that the average ages of the experimental group students are (4.17), the variance $(1,276)$, the standard deviation $(3,125)$, the average age of the control group (4.17) months, the variance $(1,558)$ and the standard deviation $(3,817)$. For the purpose of knowing the significance of the difference between the two research groups, the Ttest was used and it was found that the difference was not statistically significant at the level (0.05), as the calculated $\mathrm{T}$ value $(0.000)$ was smaller than the tabular value of $(2,000)$ and with a degree of freedom (48) according to this result The two groups are considered equal in the variable of chronological age, as shown in Table (4).

Table (4) Equivalence in the chronological age variable

\begin{tabular}{|c|c|c|c|c|c|c|c|}
\hline $\begin{array}{c}\text { Significance } \\
\text { level at } \\
(0.05)\end{array}$ & \multicolumn{2}{|c|}{ T-value } & variance & Standard deviation & SMA & $\begin{array}{c}\text { Sample } \\
\text { volume }\end{array}$ & Groups \\
\hline $\begin{array}{c}\text { Not } \\
\text { statistically } \\
\text { significant }\end{array}$ & 2,000 & 0,000 & 1,558 & 3,817 & 4,12 & 25 & Control \\
\cline { 2 - 8 } & Tabular & Calculated & 1,276 & 3,17 & 25 & Experimental \\
\hline
\end{tabular}

\section{1- Defining the educational material:}

In light of the findings of the research experience, the research requirements, and the circumstances 
surrounding the experiment, the researcher relied in presenting his educational material on some creative capabilities in the planning subject as well as drawing, and these capabilities are (flexibility, details) as the material was divided into (4 weeks) and by the reality of an educational idea or Creative ability every week with one of the materials chosen in planning and drawing, and dividing them according to behavioral goals and levels.

\section{2- Formulating behavioral goals:}

The behavioral goal is a sentence or phrase describing the final outcome of teaching, and its formulation is in the form of observable and measurable performance, as it represents an attempt to learn or the curriculum, so the process of formulating behavioral goals helps in designing the educational process and transforming it into an organized intended process, and the clarity and accuracy of behavioral goals are two basic factors driving To give the student his intended behavior. (Atallah, 2009: 74)

Based on the above, the researcher prepared a set of behavioral goals that were derived according to the cognitive aspect of Bloom's classification and for the second and third levels (understanding and application). The number of behavioral goals in their final form reached (16) behavioral goals, as shown in Appendix (2).

\section{3- Preparing teaching plans:}

To achieve the goal of the current research, the researcher prepared two types of teaching plans, the first type using the strategy of (group learning), while the second type is in the traditional way, as planning the lesson is a necessary procedure to reach a successful teaching that takes into account the nature of the learners. Based on the above, the researcher prepared (4) plans for the experimental group and (4) plans for the control group distributed over the academic weeks of the experiment, with one plan for the experimental group and one plan for the control group. A group of specialized professors and experts in art education, methods of teaching it, measurement and evaluation Appendix (1)

\section{Seventh: Research Tool (Skill Performance Assessment Scale)}

Preparing the creative capacity development measure for skill performance according to the following steps:

A. Determining the objective of the scale: The scale aims to determine the extent of the growth of the creativity capabilities of sixth grade students.

B. Defining the scale paragraphs: The skill performance assessment scale items have been determined using the following procedures:

1- Personal interviews with some art education teachers in some schools to find out the background knowledge of the nature of these measures among the sample members.

2- Reviewing previous research and studies that dealt with preparing a scale on developing creative capabilities for skill performance

3- Reviewing and analyzing studies related to the current topic of research that dealt with developing creative capacities in art education,

Table (5) shows the scale paragraphs, the creativity capacity that measures them, and the time period.

\begin{tabular}{|c|c|c|c|}
\hline Time & $\begin{array}{c}\text { The creative abilities that it } \\
\text { measures }\end{array}$ & Paragraph & No \\
\hline 10minutes & Flexibility & $\begin{array}{c}\text { Accuracy in drawing imaginary } \\
\text { elementary lines to determine the shape }\end{array}$ & 1 \\
\hline 10minutes & Flexibility & $\begin{array}{c}\text { Determine the outline and adopt them } \\
\text { as a basis for drawing details }\end{array}$ & 2 \\
\hline
\end{tabular}




\begin{tabular}{|c|c|c|c|}
\hline 10minutes & Flexibility & $\begin{array}{c}\text { The possibility of determining the } \\
\text { center point of the shape to provide } \\
\text { correct proportions of the shape }\end{array}$ & 3 \\
\hline 10minutes & the details & $\begin{array}{c}\text { The ability to implement the } \\
\text { vocabulary structure of the figure in a } \\
\text { regular engineering framework }\end{array}$ & 4 \\
\hline 10minutes & the details & $\begin{array}{c}\text { Extraction of an integrated artwork by } \\
\text { employing the major components of } \\
\text { planning }\end{array}$ & 5 \\
\hline 10minutes & Flexibility & $\begin{array}{c}\text { Illustrate the figure from a specific } \\
\text { point of view }\end{array}$ & 6 \\
\hline 10minutes & Flexibility & $\begin{array}{c}\text { Determine the four directions of the } \\
\text { drawing by the main angle of view }\end{array}$ & 7 \\
\hline 10minutes & Flexibility & $\begin{array}{c}\text { It shows the places of drawing the } \\
\text { details of the figure on the surfaces and } \\
\text { their implementation later }\end{array}$ & 8 \\
\hline 10minutes & the details & $\begin{array}{c}\text { Execute drawing shapes and motifs } \\
\text { inside the specified shape }\end{array}$ & 9 \\
\hline 10minutes & the details & $\begin{array}{c}\text { The possibility of applying a consistent } \\
\text { artwork in form and content }\end{array}$ & 10 \\
\hline
\end{tabular}

In drafting the following paragraphs, consideration has been taken:

1- The phrases should be free from ambiguity.

2- Each phrase expresses a creative ability to perform skills procedurally.
3- The term that can be measured in more than one way is excluded.

A: Determining the method for measuring the skill: The researcher put (5) response estimates for each paragraph of the scale, and Table (6) illustrates that.

Table (6) levels of skill performance

\begin{tabular}{|c|c|c|c|c|c|}
\hline very good & good & Average & Acceptable & Weak & $\begin{array}{c}\text { Performance } \\
\text { level }\end{array}$ \\
\hline 5 & 4 & 3 & 2 & 1 & Degree \\
\hline
\end{tabular}

D- Determining the answer time for the scale: As the scale was applied to an exploratory sample of (10) students, the results showed that the average response time to the paragraphs was (100) minutes.

\section{Eighth: Psychometric properties}

One of the most important psychometric properties (truthfulness and reliability) confirmed by the measurement theory, which must be met with a good degree. (Abd al-Rahman and Zankana, 1998: 159)

The following is an explanation to verify these two characteristics:

\section{1- Honesty:}


Validity is one of the most important psychometric characteristics of the test, as it indicates the ability of the test to measure what it was prepared to measure, and validity has three basic indicators: the validity of the content, the validity of the test, the validity of the construction, and the researcher's verification with two indicators:

\section{A- Validate the content:}

After completing the preparation of the test items, the researcher presented it with the content components represented by behavioral goals and instructional plans to the judges who assessed the validity of each paragraph to measure the content to be measured, so the test is considered true in its content.

\section{B- Validity of construction:}

It is the validity of the concept or the validity of the hypothetical formation, as it indicates the extent to which the test is measured to form a hypothesis or a specific concept, as it is a representation of all the researcher's actions in building and preparing the test, and indicators of construct validity and other types of validity and consistency.

\section{2- Stability:}

The scale was applied to a sample of sixth-grade students who differed from the original research sample, the number of (10) students, as the coefficient of stability of the Creative Development Scale was calculated, using the Alpha Cronbach coefficient, as the value reached (0.88) and this value is an indicator of the stability The scale and its results can be trusted and applied to the sample members, as the accepted standard for the reliability coefficient is $(0.65)$ or more.

\section{The scale in its final form:}

After calculating the psychometric characteristics, the scale now consists of (10) items to measure creativity, and accordingly, the total score $=10 \times 5$ $=50$, which is the highest score, and the lowest score $=10 \times 1=10$.

Ninth: Procedures for implementing the experiment 1. Before applying the experiment:
A. Preparing teaching plans for the two groups and the behavioral goals, and presenting them to a group of experts.

B. Conducting parity between the experimental and control groups in the aforementioned variables.

2. The actual application of the experiment.

A. The researcher studied the two groups by himself in order to avoid the difference that might result from the difference of the teacher and his ability, and his acquaintance with the variables of the experimental group.

B. Students of the two groups were exposed to the same amount of material and information.

C. Students are not allowed to move between the two groups during the implementation of the experiment.

D. The period of time for the experiment was in the first semester, spread over four academic weeks of the academic year (2019-2020).

\section{Research findings and recommendations}

\section{First: View results}

In this chapter, the researcher reviews the most important results that he reached by using appropriate statistical means between the two groups according to the scores they obtained in the test and discusses the results, conclusions, recommendations and suggestions.

\section{1- The first null hypothesis:}

There are no statistically significant differences between the average scores of the experimental group that is taught using the combination learning strategy and the control group that is taught by the traditional method at the level of (0.05) in the pretest.

To test the null hypothesis, the skills of the two research groups were tested, and the arithmetic mean of the experimental group was $(19,36)$, the standard deviation $(7,438)$, the variance $(1,488)$, and the control group had the arithmetic mean $(18,24)$ 
and the standard deviation $(6,641)$ and the variance. $(1,641)$. Where it was found that the T-value (t-test) and to know the significance of the difference between the two groups, the researcher used the T- test equal to (0.562) smaller than the tabular value of $(2,000)$ and with a degree of freedom (48) knowing that the T-test for two independent samples and Table (7) Explains that.

Table (7) the T-value calculated for the differences between the pre-test scores of the two research groups

\begin{tabular}{|c|c|c|c|c|c|c|c|c|}
\hline $\begin{array}{c}\text { Significance } \\
\text { level at } \\
(0.05)\end{array}$ & \multicolumn{2}{|c|}{$\mathrm{T}$-value } & $\begin{array}{c}\text { Degree } \\
\text { of } \\
\text { freedom }\end{array}$ & variance & Standard deviation & SMA & $\begin{array}{l}\text { Sample } \\
\text { volume }\end{array}$ & Groups \\
\hline \multirow{2}{*}{$\begin{array}{l}\text { Not } \\
\text { statistically } \\
\text { significant }\end{array}$} & Tabular & Calculated & \multirow{2}{*}{48} & 1,488 & 7,438 & 19,36 & 25 & Experimental \\
\hline & 2,000 & 0.562 & & 1,641 & 6,641 & 18,24 & 25 & Control \\
\hline
\end{tabular}

\section{2- The second null hypothesis:}

There are no statistically significant differences between the average scores of the experimental group and the control group at the level of (0.05) in the post test. To ensure the null hypothesis, the skill test was applied to the two research groups, and the arithmetic mean of the experimental group was (23.68), the standard deviation $(6,012)$, the variance $(1,202)$, and for the control group the arithmetic mean $(16,32)$, the standard deviation $(6,362)$ and the variance $(1,272)$. Where it was found that the T-test value and to know the significance of the difference between the two groups, the researcher used the Ttest equal to $(4,204)$ smaller than the tabular value of $(2,000)$ and with a degree of freedom (48) knowing that the T-test for two independent samples and Table (8) illustrates this.

Table (8) the T-value calculated for the differences between the post-test scores of the two research groups

\begin{tabular}{|c|c|c|c|c|c|c|c|c|}
\hline $\begin{array}{c}\text { Significance } \\
\text { level at } \\
(0.05)\end{array}$ & \multicolumn{2}{|c|}{$\mathrm{T}$-value } & $\begin{array}{l}\text { Degree } \\
\text { of } \\
\text { freedom }\end{array}$ & variance & Standard deviation & SMA & $\begin{array}{l}\text { Sample } \\
\text { volume }\end{array}$ & Groups \\
\hline \multirow{2}{*}{$\begin{array}{c}\text { Not } \\
\text { statistically } \\
\text { significant }\end{array}$} & Tabular & Calculated & \multirow{2}{*}{48} & 1,202 & 6,012 & 23,68 & 25 & Experimental \\
\hline & 2,000 & 4,204 & & 1,272 & 6,362 & 16,32 & 25 & Control \\
\hline
\end{tabular}

Accordingly, it rejects the null hypothesis and accepts the alternative, that is, there are statistically significant differences between the mean scores of the experimental group that is studied using the combination learning, and the control group that is taught by the traditional method at a significance level of (0.05) in the post-test.

\section{3- The third null hypothesis:}

There are no statistically significant differences between the average scores of the experimental group that are taught using the combination learning strategy at a significance level of (0.05) in the pre and post test. To test the null hypothesis, the skill test was applied to the experimental group, and the pre-test result was the arithmetic mean (19.36), the standard deviation $(7,438)$ and the variance $(1,488)$. The post test is the arithmetic mean (23.68), the standard deviation $(6,012)$ and the variance $(1,202)$, where it was found that the T-value (t-test) and to know the significance of the difference between the 
two groups, the researcher used the $\mathrm{T}$ test equal to $(3,086)$ greater than the tabular value of $(2,064)$ With a degree of freedom (24), noting that the Ttest for a correlated sample was the result of the arithmetic mean of the difference $(4,320)$ and the result of the standard deviation of the difference $(6,998)$ and Table $(9)$ shows that.

Table (9) The calculated T-value of the differences between the pre-test and post-test scores for the experimental group students

\begin{tabular}{|c|c|c|c|c|c|c|c|}
\hline \multicolumn{2}{|c|}{ T-value } & $\begin{array}{c}\text { Standard } \\
\text { deviation } \\
\text { of the } \\
\text { difference }\end{array}$ & $\begin{array}{c}\text { The } \\
\text { arithmetic } \\
\text { mean of } \\
\text { the } \\
\text { difference }\end{array}$ & variance & Standard deviation & SMA & the test \\
\cline { 1 - 5 } Tabular & Calculated & \multirow{2}{*}{6,998} & 4,320 & 1,488 & 7,438 & 19,36 & Tribal \\
\cline { 1 - 1 } 2,064 & 3,086 & & & 1,202 & 6,012 & 23,68 & Dimensional \\
\hline
\end{tabular}

Therefore, there is a statistically significant difference between the mean of the pre and post test scores for the experimental group at a significance level of $(0.05)$ in the pre and post test.

\section{Conclusions}

Through the researcher's findings, it is evident that the students of the experimental group over the control group. The researcher believes, through his review, that this superiority is due to several reasons, the most important of which are:

1. The instructional plans and their design in line with the group learning strategy, which gave students technical skills that enabled them to somewhat develop their creative abilities.

2. The segmentation of the educational process according to the analysis of technical skills and in the form of sequential steps helps to develop the creative abilities of students.

3. Teaching planning and drawing in Art Education, using the combination learning strategy, gave students artistic skills, increased motivation towards learning, and improved skill performance for them.

\section{Recommendations}

Based on the researcher's findings, the following recommendations can be formulated:

1. The necessity of adopting educational plans designed according to the group learning strategy to teach planning and drawing by the institutions of the Ministry of Education, due to their effectiveness in developing the creative abilities of students.

2. Emphasis on holding training courses for art education teachers to train them on how to use the combination learning strategy in teaching art education.

\section{Proposals}

The researcher suggests conducting studies similar to the current search for:

1. The effectiveness of the group learning strategy in developing achievement motivation for the skillful performance in art education among middle school students.

2. The effect of using the group learning strategy in teaching fourth grade students to 
acquire basic skills and develop their attitudes towards art education.

\section{References}

[1] Al Street, Abdullah and others (2000): "Program for Gifted Identification and Care", King Abdulaziz City for Science and Technology, Riyadh, Kingdom of Saudi Arabia.

[2] Al-Harbi, Abeer Abdullah (2000): "The Impact of the Creative Capacity Development Program on the Efficiency of a Sample of Special Education Teachers in the City of Riyadh," an unpublished Master Thesis, College of Education, King Saud University.

[3] Al-Rasheed, Abdul-Rahman (2000): "The innovative environment as perceived by students and its relationship to innovative thinking among middle school students in Riyadh," an unpublished master's thesis, College of Education, King Saud University.

[4] Al-Shibli, Nisreen Mahmoud Shihab (1997):

"The Impact of a Synthesis Model of Collective Learning, Control, and Perfection in the Performance of Pottery Art", Unpublished Master Thesis, Battawa University, College of Fine Arts.

[5] Al-Ezzah, Saeed Hosni (2000): "Educating the Gifted and Outstanding," Dar Al Thaqafa for Publishing and Distribution, 1st Edition, Amman, Jordan.

[6] Al-Qudah, Basil (2001): "The Impact of Learning and Cooperative Teaching Method on the Development of Creative Thinking of the Eighth Grade Students", unpublished MA Thesis, College of Education, Yarmouk University.

[7] Jarwan, Fathy Abdel-Rahman (2002): "Creativity", Dar Al-Fikr for Printing and Publishing, 1st floor, Amman, Jordan

[8] Hijazi, Sanaa (2001): "The psychology of creativity, its definition, development and measurement among children", Arab Thought House, 1st Edition, Cairo.

[9] Abdul-Rahman, Anwar Hussein, Adnan Haqqi Zangana (2007): methodological patterns and their applications in the human and applied sciences, Al-Wefaq Printing Company, Baghdad.

[10] Atallah, Michel Kamel (2009): "Methods and Methods of Teaching Science", 1st Edition, Dar Al Masirah for Publishing and Distribution, Amman

[11] Muhammad, Soha Saadi (2012): “The Effect of Using the Combined Learning Strategy on the Skills Performance of Students of the Art Education Department in the Planning Subject" Al-Fath Magazine, Issue 50.

[12] Mansour, Abdul-Majeed, and Twaijri, Muhammad (2000): "Talented People, Prospects for Care and Rehabilitation, Between Arab and International Realities", Al-Obeikan Library, Riyadh, Kingdom of Saudi Arabia.

[13] Al-Sakran, Muhammad Ahmad (1989): "Methods of Teaching Social Studies", Al Sharq Publishing House, Amman.

[14] Joyce, B. Weil M- Models of teaching (2 nd. Ed) New Jersy Prentice - Hall, Inc, 1980. 


\section{Appendices}

Appendix (1) Names of the experts and arbitrators whom the researcher has sought assistance

\begin{tabular}{|c|c|c|c|}
\hline Jurisdiction & Workplace & Name of the expert & No. \\
\hline Design & $\begin{array}{l}\text { Al-Mustansiriya University / } \\
\text { College of Basic Education }\end{array}$ & $\begin{array}{l}\text { Prof. Maha Ismail Al- } \\
\text { Sheikhly }\end{array}$ & 1 \\
\hline $\begin{array}{l}\text { Measure and } \\
\text { straighten }\end{array}$ & $\begin{array}{c}\text { Counselor / Ministry of } \\
\text { Education }\end{array}$ & $\begin{array}{c}\text { Prof. Dr. Kamel } \\
\text { Thamer Al-Kubaisi }\end{array}$ & 2 \\
\hline T. Art Education & $\begin{array}{l}\text { Al-Mustansiriya University / } \\
\text { College of Basic Education }\end{array}$ & $\begin{array}{l}\text { Prof. Dr. Amara Khalil } \\
\text { Ibrahim }\end{array}$ & 3 \\
\hline Art Education & $\begin{array}{l}\text { Al-Mustansiriya University / } \\
\text { College of Basic Education }\end{array}$ & $\begin{array}{c}\text { Prof. Dr. Hussain Ali } \\
\text { Saqi }\end{array}$ & 4 \\
\hline $\begin{array}{c}\text { T. Art } \\
\text { Education. }\end{array}$ & $\begin{array}{l}\text { Al-Mustansiriya University / } \\
\text { College of Basic Education. }\end{array}$ & $\begin{array}{l}\text { Prof. Dr. Firas Ali Al- } \\
\text { Kinani }\end{array}$ & 5 \\
\hline $\begin{array}{c}\text { Educational } \\
\text { administration }\end{array}$ & $\begin{array}{c}\text { Educational supervisor / } \\
\text { Baghdad Education Al-Karkh / } \\
2\end{array}$ & $\begin{array}{c}\text { Prof. Dr. Souad Khader } \\
\text { Al-Rawi }\end{array}$ & 6 \\
\hline $\begin{array}{c}\text { Learn } \\
\text { kinesthetic }\end{array}$ & \begin{tabular}{|c} 
General Directorate of \\
Education in Baghdad Al-Karkh \\
/ 2
\end{tabular} & Prof. Dr. Haider Nawar & 7 \\
\hline $\begin{array}{l}\text { Teaching } \\
\text { methods }\end{array}$ & $\begin{array}{c}\text { General Directorate of } \\
\text { Education in Baghdad Al-Karkh } \\
\text { / } 2\end{array}$ & Dr. Ola Hussein Alwan & 8 \\
\hline
\end{tabular}

\section{Accessory (2)}

Behavioral goals

\begin{tabular}{|c|c|c|}
\hline Creative type & Subject & $\begin{array}{c}\text { The time period for applying the } \\
\text { experiment }\end{array}$ \\
\hline Flexibility & Planning & The first week \\
\hline
\end{tabular}

\begin{tabular}{|c|c|c|}
\hline Measures & Behavioral goal & No. \\
\hline Understanding & $\begin{array}{c}\text { Controls by selecting the center point of a } \\
\text { shape to provide correct proportions of the } \\
\text { shape }\end{array}$ & 1 \\
\hline Understanding & $\begin{array}{c}\text { Show imaginary prime lines to define } \\
\text { shapes }\end{array}$ & 2 \\
\hline Understanding & $\begin{array}{c}\text { It clarifies the outlines and uses it as a } \\
\text { basis for drawing details }\end{array}$ & 3 \\
\hline
\end{tabular}




\section{Understanding}

Distinguish between drawing tight geometric shapes to emphasize the subject's vocabulary within the frame

\begin{tabular}{|c|c|c|}
\hline Creative type & Subject & $\begin{array}{c}\text { The time period for applying the } \\
\text { experiment }\end{array}$ \\
\hline the details & Planning & The second week \\
\hline
\end{tabular}

\begin{tabular}{|c|c|c|}
\hline Measures & Behavioral goal & No. \\
\hline The application & $\begin{array}{c}\text { It employs the major components of } \\
\text { planning }\end{array}$ & 1 \\
\hline The application & $\begin{array}{c}\text { Performs the vocabulary structure of the } \\
\text { figure in a regular geometric framework of } \\
\text { the subject }\end{array}$ & 2 \\
\hline The application & $\begin{array}{c}\text { Draws the inner and outer lines of the } \\
\text { shapes while observing the proportions }\end{array}$ & 3 \\
\hline The application & Extracts integrated artwork from fonts & 4 \\
\hline
\end{tabular}

\begin{tabular}{|c|c|c|}
\hline Creative type & Subject & $\begin{array}{c}\text { The time period for applying the } \\
\text { experiment }\end{array}$ \\
\hline Flexibility & Draw & Only the third week \\
\hline
\end{tabular}

\begin{tabular}{|c|c|c|}
\hline Measures & Behavioral goal & $\mathrm{T}$ \\
\hline Understanding & $\begin{array}{c}\text { It defines a solid and regular geometric } \\
\text { framework for the vocabulary of shape in } \\
\text { the subject }\end{array}$ & 1 \\
\hline Understanding & $\begin{array}{l}\text { The figure is illustrated by a central point } \\
\text { and identifies the four directions to provide } \\
\text { correct proportions of the figure }\end{array}$ & 2 \\
\hline Understanding & Shows the drawing from a certain angle & 3 \\
\hline Understanding & $\begin{array}{c}\text { It shows the places of drawing the details } \\
\text { of the shape of the surfaces and their } \\
\text { implementation later }\end{array}$ & 4 \\
\hline
\end{tabular}

Creative type

Subject

The time period for applying the experiment 


\begin{tabular}{|l|l|l|}
\hline the details & Draw & Only the fourth week \\
\hline
\end{tabular}

\begin{tabular}{|c|c|c|}
\hline Measures & Behavioral goal & No. \\
\hline The application & $\begin{array}{c}\text { Draws a central point and lines for the four } \\
\text { directions }\end{array}$ & 1 \\
\hline The application & $\begin{array}{c}\text { Uses a specific geometric shape in which } \\
\text { the subject of the drawing is framed }\end{array}$ & 2 \\
\hline The application & $\begin{array}{c}\text { Performs motifs etc inside the specified } \\
\text { shape }\end{array}$ & 3 \\
\hline The application & $\begin{array}{c}\text { They employ geometric shapes and } \\
\text { combine them in a distinct artwork }\end{array}$ & 4 \\
\hline
\end{tabular}

\section{Accessory (3)}

The form for assessing the skill performance

\begin{tabular}{|c|c|c|c|c|c|c|}
\hline \multicolumn{5}{|c|}{ The student performs the skills well } & \multirow{2}{*}{ Paragraph } & \multirow{2}{*}{ No. } \\
\hline $\begin{array}{l}\text { very } \\
\text { good }\end{array}$ & good & Average & Acceptable & Weak & & \\
\hline & & & & & $\begin{array}{l}\text { Accuracy in drawing imaginary elementary } \\
\text { lines to determine the shape }\end{array}$ & 1 \\
\hline & & & & & $\begin{array}{l}\text { Determine the outlines and adopt them as a } \\
\text { basis for drawing details }\end{array}$ & 2 \\
\hline & & & & & $\begin{array}{l}\text { The possibility of determining the center } \\
\text { point of the shape to provide correct } \\
\text { proportions }\end{array}$ & 3 \\
\hline & & & & & $\begin{array}{l}\text { The ability to implement the vocabulary } \\
\text { structure of the figure in a regular } \\
\text { engineering framework }\end{array}$ & 4 \\
\hline & & & & & $\begin{array}{l}\text { Extraction of an integrated artwork by } \\
\text { employing the major components of planning }\end{array}$ & 5 \\
\hline & & & & & $\begin{array}{l}\text { Illustrate the figure from a specific point of } \\
\text { view }\end{array}$ & 6 \\
\hline & & & & & $\begin{array}{l}\text { Determine the four directions of the drawing } \\
\text { by the main angle of view }\end{array}$ & 7 \\
\hline & & & & & $\begin{array}{l}\text { It shows where to draw the details of the } \\
\text { figure on the surfaces and their } \\
\text { implementation later }\end{array}$ & 8 \\
\hline
\end{tabular}




\begin{tabular}{|c|l|l|l|l|l|}
\hline & & & & $\begin{array}{c}\text { Execute drawing shapes and decorations } \\
\text { inside the specified shape }\end{array}$ & 9 \\
\hline & & & & $\begin{array}{c}\text { The possibility of applying a consistent } \\
\text { artwork in form and content }\end{array}$ & 10 \\
\hline
\end{tabular}

\section{Accessory (4)}

Teaching plans

An example of a daily teaching plan for the experimental group

Taught using an additive learning strategy

Row: day and date:

Subject: Art Education

Topic: Planning Time period: First week Creative Capabilities: Flexibility

Special objective: After completing the lesson, the student will be able to:

1- Controls by selecting the center point to provide correct proportions for the shape.

2- Shows the imaginary initial lines to define the shapes.

3- Clarifies the outlines and adopts it as a basis for drawing details.

4- Distinguish between drawing tight geometric shapes to emphasize the subject's vocabulary within the frame.

Teaching aids: smart board, data show display device, computer.

Teaching method: application of the group learning strategy.

\section{Introduction: (5 minutes)}

Preparing students' minds for the topic of the lesson through a general review of a previous lesson that was viewed by the subject teacher and trying to relate it to the basic concepts of the current lesson topic about planning and its most important basic requirements.

\section{Presentation: (30 minutes)}

1- We start with a specific point or angle to the center of the figure, so that the proportions and distribution of the shape within the area are correct, where we draw a central point on the board and distribute the directions as in Figure (A).

Figure A

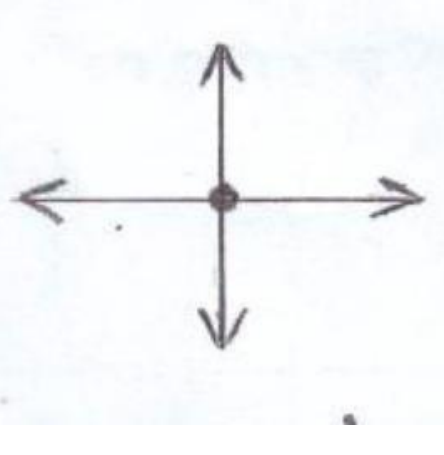


2- After drawing the outline lines, we draw initial imaginary lines to determine the shape to be drawn, and these lines are simple with the comfort of the pen and with quick and simple movements to be the basis for drawing the main shape. As in figure (b)

Figure (B)

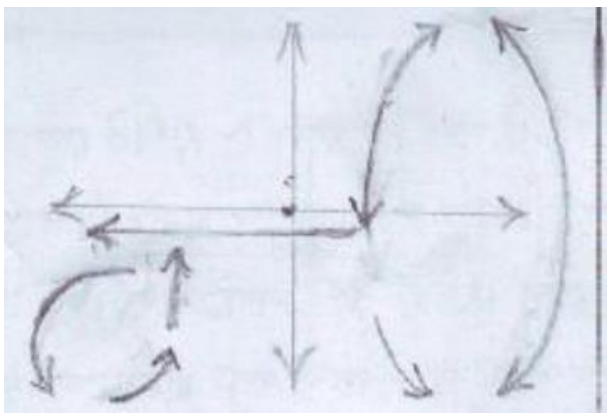

3- The teacher provides a preliminary explanation by drawing external diagrams for some shapes, which are adopted as a vertical frame to start work, which is used as a base for distributing the primary lines and correctly distributing proportions, shapes and areas within the main planning. (Figure C)

\section{Figure (C)}

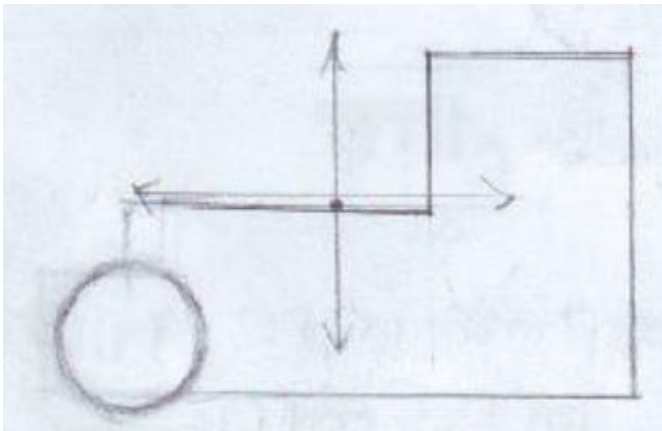

4. The teacher draws regular geometric shapes to confirm the vocabulary of the topic within the frame, to structure the vocabulary of the topic and arrange the figures separately. As in figure (d).

\section{Figure (D)}

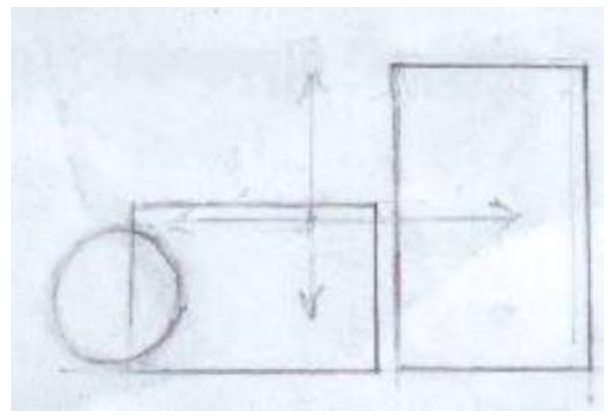

After presenting the scientific material and to ensure the mastery of the material from all students to reach the goal of the lesson and according to the group learning strategy, so we take a full additional session to explain the steps of work using the strategy subject of the lesson as follows:

1- We choose the scientific material for the lesson (planning).

2- Explanation of an introductory introduction on the topic.

3- We show the student the reasons for learning this topic and its consequences.

4- It provides students with instructions and instructions on how to work in a group manner. 
5- We define work tools and supplies.

6- Determine the movements and skills needed for work.

Calendar: (10 minutes)

Dear student:

Based on the above and through our presentation of the subject of the lesson, answer the following skill question:

Draw what you have learned in multiple steps and not in one form, such as a shape for the outline lines, a second figure to put a main starting point, and a third figure for drawing the illusory primary lines and the distribution of proportions and areas. As in Figure (E).

\section{Figure E}

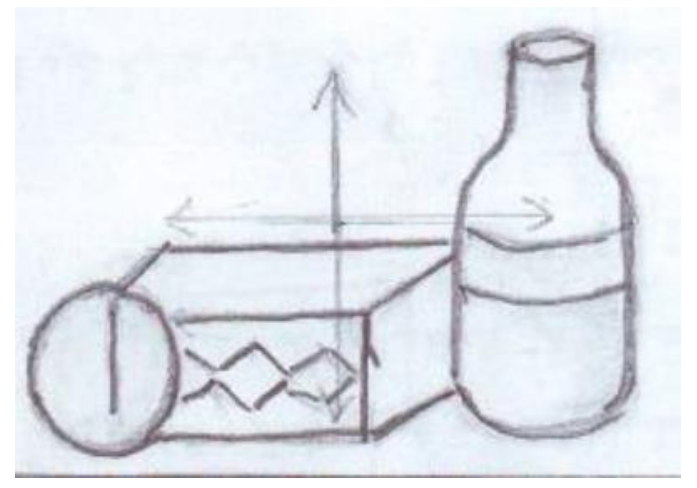

